\title{
REFUGEE CRISIS REPRESENTATION ON GERMAN ONLINE PRESS: THE CASE OF AYLAN KURDI
}

\section{A representação da crise dos refugiados na imprensa on-line alemã: o caso de Aylan Kurdi}

David Ramírez Plascencia*

\begin{abstract}
This paper is focused in examining the digital news representation of Syrian refugee crisis and the conformation of the reader's opinions in Germany. Data collection will be addressed on reviewing German online news and the reader's comments related with one remarkable event during the actual migration crisis in Europe: The note about the child Aylan or Alan Kurdi, that drowned in the coast of Turkey in September 02 of 2015. The main aim of this paper is to understand the role of media crisis representation on the opinions of German people. How does media shape public reactions in pro and against helping refugees? And what kind of actions could the European authorities undertake to protect the human rights of refugees and to diminish hate discourse online.
\end{abstract}

Keywords: hate discourse, Social Media, European migration crisis, digital journalism, cyber-ethics.

Resumo. Este artigo examina a representação presente em notícias digitais sobre a crise dos refugiados sírios e a configuração das opiniões do leitor na Alemanha. A coleta de dados será abordada a partir da revisão de notícias on-line na Alemanha e de comentários do leitor relacionados com um acontecimento notável durante a atual crise de migração na Europa: a notícia sobre a criança Aylan ou Alan Kurdi, que se afogou na costa da Turquia em 2 de setembro de 2015. O objetivo principal deste trabalho é compreender o papel da representação midiática da crise nas opiniões dos alemães. Como a mídia forma as reações públicas a favor e contra a ajuda aos refugiados? E que tipo de ações as autoridades europeias poderiam assumir para proteger os direitos humanos dos refugiados e para diminuir o discurso de ódio on-line.

Palavras-chave: discurso de ódio, mídia social, crise migratória europeia, jornalismo digital, ciberética.

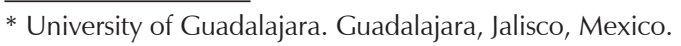




\section{Context}

The recent Syrian and African migration phenomena represents one of the most important migration crisis since the end of the World War II, in fact, there is not a single European country that is beyond the effects of this event. This emergency has been triggered by some complex and diverse factors, like the profound political changes in North Africa englobed under the title of "Arabic Spring" that eroded traditional authoritarian governments in several countries as in the case of Egypt and Libya, but as a tangential effect it has caused economic depression and social instability, the recent emergence of the terrorist group named as The Islamic State (IS) and the restless civil war in Syria that has forced millions of people to escape in weak and dangerous ships to search asylum in Europe. During this crisis, important and sad events have drastically changed the strategies and public consideration concerning refugees: the considerable increment of casualties in between migrants in the Mediterranean Sea, especially the terrible deceased of about 500 African migrants in the coast of Lampedusa Island in Italy on October of 2013. Additionally, the terrorist attacks in Paris (2015), Brussels (2016) and Barcelona (2017) have increased hostility toward Muslim religion and the Arabic culture and, particularly, against Syrian migrants who are accused of being terrorists that cross the borders dressed up as refugees. Migration problems and economic crisis have stimulated the resurgent of nationalism, xenophobic and anti-migration views along the continent, especially in France and Germany ${ }^{1}$. The triumph of Marine Le Pen was particularly remarkable in the city of Paris, and the rising of far-right politicians like Frauke Petry and political parties as PEGIDA (Patriotische Europäer gegen die Islamisierung des Abendlandes) in Germany, that have gained political sympathies using an anti-migration agenda ${ }^{2}$.

Surprisingly not, many far-right anti-migrant activists do not even consider themselves as racist or xenophobic, they claim that most of their arguments against the entrance of refugees stand on economic and security basics. However, a deeper analysis of their discourse clearly shows how these arguments are settled on traditional racist and xenophobic stereotypes ${ }^{3}$. Actually, these traditional and unresolved problems, xenophobia and migration, combined with other factors like terrorism and the huge migration flows, are boosting a bigger and more dangerous situation: by now far-right political parties and their sympathizers are seeking to establish more rigid and complex migration mechanisms inside the European Union, not only when people try to enter to the European Union, but inside the Schengen Zone, they are looking to

\footnotetext{
GIGONA, Radina, HUME, Tim. Mob calls for assaults on migrants in Sweden.

SMALE, Alison. Germany's Embrace of Migrants Spawns Rise of Far-Right Leader.

3 GEWORKIAN, Alexej. 'Crisis migratoria' en Alemania, acciones racistas y solidaridad con los refugiados.
} 
establish more sever boundary controls or as in the case of Great Britain, to encourage the exit from the Union. Many of these new anti-migration parties are not only against African or Syrian migration, but also against the inner existence of open flows of individuals and goods. Most of them, as in the case of counties in the Balkans and East Europe, are not happy with current migration policies commanded from Strasburg. So many politicians have been gathering popular discontent and trying to impost novel measures to provincialize and stretch borders ${ }^{4}$. These actions could not only affect economic activities like tourism, but can also be taken to the extremes, it could be an important barrier that could compromise the very existence of the Schengen space, one of the most important and symbolic achievements of the European Union since its establishment. In the case of activism pro-migration, along with the problem of dealing with a more adverse panorama, non-profits organizations that pursue a more humanitarian treatment toward Syrians and Africans although they do not always share the same political agenda with the people they are trying to help. A long these years, there have been important discrepancies in between their goals. Many support and welcome the refugees and deplore how European authorities are dealing with the problem, but at the same time, they consider the situation as a consequence of globalization and liberalism policies around the world, they search for a wider solution that is almost unreachable. On the contrary, Syrian migrants are focused mainly in arriving to Europe, to normalize their situation and to get a job ${ }^{5}$, these kinds of discrepancies are not helping much when trying to solve the entire situation and finding a proper mechanism that could guarantee for one side, the protection of human rights, and for the other, the homeland security. By now, with the agreement between Ankara and the European Union in March of 2016, the possibility to guarantee a fair treatment to asylum seekers looks compromised.

\section{Theoretical considerations}

Migration is a stressing and complex phenomenon that has several outcomes and impacts, one them is xenophobia. Research about anti-minority discourse in media is, of course, not new ${ }^{6}$. There are some well examples of how media, particularly printed and online press, could be an important source not only to understand how broadcasting companies display, tacitly or not, racist discourse. Like how online press uses certain vocabulary to stimulate

\footnotetext{
${ }^{4}$ HESS, Sabine, TSIANOS, Vassilis. Europeanizing Transnationalism! Provincializing Europe! Konturen eines neuen Grenzregimes; AMELINA, Anna, HORVATH, Kenneth, MEEUS, Bruno. Migration and Social Transformation: Interdisciplinary Insights and European Perspectives.

5 FADAEE, Simin. The Immigrant Rights Struggle, and the Paradoxes of Radical Activism in Europe.

6 SLAVÍČKOVÁ, Tess, ZVAGULIS, Peter. Monitoring anti-minority rhetoric in the Czech print media: A critical discourse analysis.
} 
the reader's opinions into a determinate direction? ${ }^{7}$. Concerning Syrian migrants and the use of stereotypes, a recent inquire states how social media discourse, like Twitter communications, tends to use certain visual composition when depicting migrants in order to create a particular and unidirectional conception, like when a newspaper inclines to portrait aisled Syrian men without the presence of children or women ${ }^{8}$. The use of traditional stereotypes for threatening one religion and ethnic group is not unusual. We can go back far in time and search inside the works of William Shakespeare or the folklore tales of Brother Grimm concerning Jewish portraits as symbols of treachery and avarice. Many authoritarians' regimens have used these portraits to motivate the community angry against marginal groups and minorities, this was the case in animosity against Gypsies, homosexuals and the Jewish during the Second World War, or more recently with racism in South Africa ${ }^{9}$. In present days, in the context of migration crisis and the generalized use of social media and mobile devices, the diffusion of old-style imaginary in the form of visual and textual memes through the Internet has become an important tool to spread mainly two kinds of discourses: One of them created to get support and relief for refugees. The other one to praise migratory controls and deportation of people. As it has happened historically, when an economic or war crisis emerges in a certain place, radicalism began spreading in between public opinion. In the case of Europe, as the economic crisis of 2008 started affecting welfare and employment, people are more reticent to accept refugees ${ }^{10}$.

The use of specific words as instruments to discriminate is a common practice in public administration. As a particular study has asserted the use of "innocuous" words in certain contexts have served to establish segregation and, at the end, to affect a particular group ${ }^{11}$. So is the case when a photo of male Syrians migrants is used to deplore terrorism, or when economic argumentations are used for praising nationalism and condemning foreigners. Regarding the United Kingdom asylum seeker policies, the use of the word "genuine asylum-seeker" is not an empty phrase, but a form to give "free pass" to functionaries to judge, under unclear parameters, who is a "genuine" and who is an "untruthful" asylum seeker" ${ }^{12}$. This of course could lead to

7 CLARE, Matthew, ABDELHADY, Dalia. No longer a waltz between red wine and mint tea: The portrayal of the children of immigrants in French newspapers (2003-2013); HOLMES, Seth M., CASTAÑEDA, Heide. Representing the 'European Refugee Crisis' in Germany and beyond: Deservingness and Difference, Life and Death.

8 RETTBERG, Jill Walker, RADHIKA, Gajjala. Terrorists or cowards: negative portrayals of male Syrian refugees in social media.

9 JANKS, Hilary. Critical Discourse Analysis as a Research Tool.

${ }^{10}$ COHEN, Roger. Germany, Refugee Nation.

${ }^{11}$ OLSEN, Christopher et alii. 'Other' Troubles: Deconstructing Perceptions and Changing Responses to Refugees in Canada.

12 KIRKWOOD, Steve et alii. The Language of Asylum. 
arbitrary decision based on subjectivities. This is the problem when dealing with an open terminology, it could be used, and is used, to discriminate. When a newspaper declares, "there is many economic migrants in between Syrians". This information is prejudiced, because the media does not provide further evidences to support this affirmation, and "trickily" opens the door to misunderstanding, confusion and ambiguities. Many people who read the information could imply that almost all migrants are not really in danger in their countries and they are looking only to take advantage of public welfare.

Because the ubiquitous of information technologies in between actual migration phenomena, it is not strange that one of the most important channels to study racism and xenophobic discourse stands on information generated in virtual spaces, especially in social media. In terms of this work discourse will refer to interconnected ideas that spread using diverse media, like the radio, television, Internet, and so on ${ }^{13}$. Ideological discourse embraces communications that flows around media to transmit an identity message to a wide public ${ }^{14}$. The term identity is always related with the consideration that some groups share a common imaginary and share same goals as a group ${ }^{15}$. This article focused on working with discourse, and more specific with discourse in digital media ${ }^{16}$. Discourse in digital media diverges from traditional one, the radio or television, due to the fact that it could embrace all conventional channels, in a simple website it is possible to post audio, video, text and photographs, having an interactive dialogue with many people and accessing to several multimedia resources at the same time. So in the case of digital discourse we could mention the following characteristics: a) it could be synchronous and asynchronous, b) it is flexible and scalable, c) it is more accessible, people can view and share information from computers and mobile devices, d) it could potentially reach thousands of people around the world in a matter of seconds, e) information could be shared using many platforms and formats, from textual to video and so on, and f) people can access info almost freely and without charge.

But as it happens in other media, there is an inner inclination in news media to influence the preferences and opinions of their public, sometimes editorials use arguments to normalize a certain discourse, displaying its version as the unique and possible report of a deeper and complex phenomenon ${ }^{17}$. This is generally a consequence of an action to control and to dominate public

\footnotetext{
${ }^{13}$ JONES, Rodney H. Discourse and Digital Practices: Doing Discourse Analysis in the Digital Age.

${ }^{14}$ BENWELL, Bethan, STOKOE, Elizabeth. Discourse and Identity.

15 Ibidem.

${ }^{16}$ O'KEEFFE, Anne. Media and Discourse Analysis.

${ }^{17}$ RAMBE, Patient. Critical Discourse Analysis of Collaborative Engagement.
} 
discourse ${ }^{18}$. When studying the implication of racist discourse concerning migratory phenomena, there is more than just the use of words and graphics. There are so many archetypical symbols and meanings associated with the particular use of one word. In the case of this paper, the analysis will be focused on finding how the portrait of information about migration crisis in German online news impacts the interpretation and comments in between the readers. Concerning news, this paper agrees with some views that it is important to review headlines as an important place were authors try to assert crucial points not only to catch the reader's attention but to express a partial line in respect to a specific event ${ }^{19}$. One of the most important destinations of Syrian migration is Germany, a country that traditionally has had confronting and diverse opinions concerning minorities ${ }^{20}$. Consequently, on one side, the country has one of the most well planned and organized refugee asylum system, contrary to other Europeans countries ${ }^{21}$. But in the other hand, there is an important tradition of racism and anti-Semitist thinking, especially in the east of the country. The analysis of material has been achieved in three important phases:

a) The first move was related with selecting one relevant event, b) after that, two of the top newspapers in Germany were selected to find the specific notes c) then information was selected, categorized and analyzed.

Concerning the first stage, (a) selecting the note, one representative event was chosen: the note of the drown child Alan Kurdi or Aylan Kurdi, in the coast of Turkey in September 02, 2015. This was selected due to the fact that this terrible dead gave an emblematic "face" to the problem and has had a deep impact around the world. b) On the second stage, two main German newspapers were selected in between the most significant and broadcasted ${ }^{22}$ : Die Welt ${ }^{23}$, owned by Springer Group, editorial line: centre-right; Süddeutsche Zeitung ${ }^{24}$, owned by Verlag Group, editorial line: centre-left. In order to select a specific report, two conditions were required (1) It must be fully accessible to all without the need of a subscription, and (2) It had to be able to post commentaries about the news. All information and comments were consulted directly on German language and translated into English by the author. The extracts from the news and comments were transcript as they appeared originally on the platform.

\footnotetext{
${ }_{18}$ VAN DIJK, Teun A. Critical Discourse Analysis.

19 TEO, Peter. Racism in the News: A Critical Discourse Analysis of News Reporting in Two Australian Newspapers.

${ }^{20}$ ADAM, Heribert. Xenophobia, Asylum Seekers, and Immigration Policies in Germany.

${ }^{21}$ DEL BARRIO, Ana. No es lo mismo ser refugiado en Alemania que en España.

22 BBC. The Press in Germany.

${ }^{23}$ Cf. <http://www.welt.de>.

${ }^{24}$ Cf. <http://www.sueddeutsche.de $>$.
} 


\section{Methodology and Data Analysis}

The case of Alan Kurdi or Aylan Kurdi was chosen mainly because its wide impact through different media around the world, and due to the fact that it has served as a symbol of the casualties triggered by the crisis during the years. Aylan Kurdi was found dead in the coast of Turkey on September 2, 2015. In the same incident died his brother Galip of 5 years old and his mother Rehan too. Unfortunately, the history of Aylan was just one among many cases of people trying to escape from war and famine in Africa and The Middle East. What is illustrative about his history is how it became a viral spread along the traditional and digital media, and even reached presidents and famous music bands like U2. In order to explore Aylan's history portrait in German media and its influence in public debate one note and its correspondent commentaries where carefully reviewed. When reviewing German newspapers online it is noticeable that there is a lot of participation and exchange between the readers. In the case of the two newspapers revised, Süddeutsche Zeitung and Die Welt, this engagement is evident. In order to select one note about the incident, it has to be open to all readers without fee and people could be able to post commentaries and to debate inside the platform. To post information, it was mandatory in both newspapers to have a profile in at least one of the following social media: Facebook, Disqus, Twitter, or Google. This requirement, in fact, not only guarantees that people can easily access into the media, but they can, under certain parameters, share their opinions on the proper social media platform. Taking a look to the news headlines and summaries (See table 1), there is one significant fact: Die Süddeutsche Zeitung has a separated place to post comments about the news. Under these parameters, the main headline clear and unintentional refers to the case of Aylan, "Aylan Kurdi, drei Jahre alt, ertrunken im Mittelmeers" (Aylan Kurdi, 3 years old, drowned in The Mediterranean Sea), but when people want to comment about the news, and browse to the next site to post a comment about the news, there is another different headline and summary, that asks about "Welche Schuld trägt Deutschland an der Flüchtlingskrise?" (What blame for Germany at the refugee crisis ?). In this case, the media is trying to channel all Aylan Kurdi case's impressions into a moral guilty fact. 
Table 1. Alan Kurdi or Aylan Kurdi Dead Coverture

\begin{tabular}{|c|c|c|}
\hline Media & $\begin{array}{l}\text { Süddeutsche Zeitung (http://www. } \\
\text { sueddeutsche.de) }\end{array}$ & Die Welt (http://www.welt.de) \\
\hline Internet Address & $\begin{array}{l}\text { Internet address for the news http://www. } \\
\text { sueddeutsche.de/politik/fluechtlinge- } \\
\text { aylan-kurdi-drei-jahre-alt-ertrunken-im- } \\
\text { mittelmeer-1.2633197 } \\
\text { Commentaries http://www.sueddeutsche. } \\
\text { de/politik/ihr-forum-welche-schuld-traegt- } \\
\text { deutschland-an-der-fluechtlingskrise-1.2633064 }\end{array}$ & $\begin{array}{l}\text { http://www.welt.de/debatte/ } \\
\text { kommentare/article146020565/Ein- } \\
\text { totes-Kind-Soll-man-es-zeigen.html }\end{array}$ \\
\hline Date & September 32015 & September 32015 \\
\hline Headline & $\begin{array}{l}\text { (News Headline) Aylan Kurdi, drei Jahre alt, } \\
\text { ertrunken im Mittelmeer } \\
\text { (Commentaries Site Headline) Welche Schuld } \\
\text { trägt Deutschland an der Flüchtlingskrise? }\end{array}$ & Ein totes Kind. Soll man es zeigen? \\
\hline English translation & $\begin{array}{l}\text { (News Headline) Aylan Kurdi, } 3 \text { years old, } \\
\text { drowned in The Mediterranean Sea. ( } \mathrm{CH} \text { ) What } \\
\text { blame for Germany at the refugee crisis? }\end{array}$ & $\begin{array}{l}\text { The death of a child. Should we show } \\
\text { it? }\end{array}$ \\
\hline Summary & $\begin{array}{l}\text { (News Summary) Das Foto des toten Jungen } \\
\text { am Strand von Bodrum geht um die Welt. } \\
\text { Internationale Medien haben herausgefunden, } \\
\text { wer er war - und warum seine Familie die Fahrt } \\
\text { über das Meer auf sich nahm. (CSS) Ungarns } \\
\text { Regierungschef Viktor Orbán bezeichnet die } \\
\text { Flüchtlingskrise als "deutsches Problem". Die } \\
\text { Bundesrepublik habe Syrer "an den gedeckten } \\
\text { Tisch eingeladen". Nach dem umstrittenen } \\
\text { Grenzzaun kündigt er neue Maßnahmen gegen } \\
\text { Asylsuchende an. }\end{array}$ & $\begin{array}{l}\text { Soll man das Foto des im Mittelmeer } \\
\text { ertrunkenen und in der Türkei an den } \\
\text { Strand gespülten syrischen Jungen } \\
\text { veröffentlichen? Die "Welt"-Redakteure } \\
\text { Matthias Kamann und Alan Posener im } \\
\text { Pro \& Contra. }\end{array}$ \\
\hline English Translation & $\begin{array}{l}\text { (News Summary) The picture of dead young } \\
\text { people on The Beach from Bodrum (Turkey) } \\
\text { to all the world. International media have } \\
\text { found out who he was, and why his family took } \\
\text { the trip across the sea? (CST) Hungary Prime } \\
\text { Minister Viktor Orbán referred to the refugee } \\
\text { crisis as "German problem". The Federal } \\
\text { Republic had Syrians "invited to the dinner } \\
\text { table". After the controversial border fence, } \\
\text { he announces new measures against asylum } \\
\text { seekers. }\end{array}$ & $\begin{array}{l}\text { Should we publish the picture of the } \\
\text { drowned in the Mediterranean and } \\
\text { in Turkey beach flushed Syrian boy? } \\
\text { Die "Welt" Editorial Offices Matthias } \\
\text { Kamann and Alan Posener in Pros \& } \\
\text { Cons. }\end{array}$ \\
\hline $\begin{array}{l}\text { Number of } \\
\text { comments }\end{array}$ & $328 \mathrm{C}$ & $93 \mathrm{C}$ \\
\hline
\end{tabular}

Source: Author.

This action of segregating the debate from the main note and to another site, and to publish another headline and summary in the commentaries section has two main purposes: to vanish the impact of the little boy history, and to instigate defensiveness in readers (See table 2). 
Table 2. Alan Kurdi or Aylan Kurdi, news' commentaries

\begin{tabular}{|c|c|c|c|c|}
\hline $\begin{array}{l}\text { Type of } \\
\text { Comments }\end{array}$ & Pro-Migration & & Versus-Migration & \\
\hline $\begin{array}{l}\text { Süddeutsche } \\
\text { Zeitung } \\
\text { (Centre-Left) }\end{array}$ & $\begin{array}{l}\text { Wir bekommen eine } \\
\text { Ahnung, welche } \\
\text { Zuwanderung } \\
\text { uns erwartet, } \\
\text { wenn es der } \\
\text { Weltgemeinschaft } \\
\text { nicht gelingt, die } \\
\text { drängendsten } \\
\text { globalen Probleme } \\
\text { zu lösen, wie z.B. } \\
\text { Erderwärmung, }\end{array}$ & $\begin{array}{l}\text { Ich war vor Kurzem im } \\
\text { Krankenhaus, meine } \\
\text { Hauptkrankenschwester } \\
\text { war Bosnierin, die } \\
\text { meisten anderen } \\
\text { Pflegekräfte und auch } \\
\text { Teile der Ärzteschaft } \\
\text { keine Deutschen. } \\
\text { Mit allen war ich } \\
\text { sehr zufrieden. } \\
\text { Deutschland wird } \\
\text { mittel- und langfristig } \\
\text { auch von diesen } \\
\text { Flüchtlingen sehr } \\
\text { profitieren. }\end{array}$ & $\begin{array}{l}\text { Wir leisten uns } \\
\text { eines der dümmsten } \\
\text { Einwanderungssysteme. } \\
\text { Jeder darf zu uns } \\
\text { kommen, egal ob er zu } \\
\text { unserm Wertesystem } \\
\text { passt oder nicht. }\end{array}$ & $\begin{array}{l}\text { Mit ihren } \\
\text { Willkommensgrüssen } \\
\text { und europaweit } \\
\text { sehr grosszügigen } \\
\text { Leistungen für } \\
\text { Asylbewerber } \\
\text { trägt die } \\
\text { Bundesregierung } \\
\text { und ein Grossteil } \\
\text { der deutschen } \\
\text { Medien eine } \\
\text { Mitschuld am } \\
\text { grossen Strom der } \\
\text { Flüchtlinge nach } \\
\text { Europa. }\end{array}$ \\
\hline $\begin{array}{l}\text { English } \\
\text { Translation }\end{array}$ & $\begin{array}{l}\text { We get a clue } \\
\text { of which kind } \\
\text { of immigration } \\
\text { awaits us if the } \\
\text { international } \\
\text { community does not } \\
\text { succeed in solving } \\
\text { the most urgent } \\
\text { global problems, } \\
\text { such as global } \\
\text { warming, }\end{array}$ & $\begin{array}{l}\text { I was recently in the } \\
\text { hospital, my main } \\
\text { nurse was Bosnian, } \\
\text { most other nurses } \\
\text { and also part of the } \\
\text { medical staff were } \\
\text { not German. With all } \\
\text { I was very pleased. } \\
\text { Germany, in the } \\
\text { mid and long term, } \\
\text { benefits from these } \\
\text { refugees. }\end{array}$ & $\begin{array}{l}\text { We provide one of the } \\
\text { most stupid immigration } \\
\text { systems. Anyone may } \\
\text { join us, regardless of } \\
\text { whether he does not fit } \\
\text { or not into our system } \\
\text { of values. }\end{array}$ & $\begin{array}{l}\text { With their words } \\
\text { of welcome and } \\
\text { the very generous } \\
\text { benefits for asylum } \\
\text { seekers in Europe, } \\
\text { the German } \\
\text { government and } \\
\text { German media } \\
\text { share responsibility } \\
\text { of the large flow of } \\
\text { refugees to Europe. }\end{array}$ \\
\hline $\begin{array}{l}\text { Die Welt } \\
\text { (Centre- } \\
\text { Right) }\end{array}$ & $\begin{array}{l}\text { Deren Wirtschaft } \\
\text { wird bewusst } \\
\text { zerstört. Ja, WIR } \\
\text { sind verantwortlich } \\
\text { für das Elend. }\end{array}$ & $\begin{array}{l}\text { Heil dem Kapital!! } \\
\text { Und möge es sich } \\
\text { vermehren. Es ist nur } \\
\text { ein Zeichen unserer } \\
\text { Zeit, dass Menschen } \\
\text { nichts mehr wert } \\
\text { sind und nur noch } \\
\text { als Humankapital } \\
\text { bezeichnet werden. }\end{array}$ & $\begin{array}{l}\text { In Muslimischen } \\
\text { Ländern sieht man } \\
\text { solche Bilder jeden Tag, } \\
\text { warum wird das jetzt } \\
\text { auf einmal weltweit } \\
\text { gezeigt? Wir werden } \\
\text { manipuliert je nachdem } \\
\text { wie es Politikern dient. }\end{array}$ & $\begin{array}{l}\text { Solche Bilder } \\
\text { werden auch gerne } \\
\text { instrumentalisiert, } \\
\text { um Mitleid und } \\
\text { Betroffenheit zu } \\
\text { erwecken. }\end{array}$ \\
\hline $\begin{array}{l}\text { English } \\
\text { Translation }\end{array}$ & $\begin{array}{l}\text { Their economy } \\
\text { is deliberately } \\
\text { destroyed. Yes, WE } \\
\text { are responsible for } \\
\text { the misery. }\end{array}$ & $\begin{array}{l}\text { Hail to the capital!! } \\
\text { And it may multiply. } \\
\text { It's just a sign of the } \\
\text { time that people are } \\
\text { worthless and are } \\
\text { referred to only as } \\
\text { human capital. }\end{array}$ & $\begin{array}{l}\text { In Muslim countries we } \\
\text { see such pictures every } \\
\text { day, why is this now } \\
\text { shown to the world? } \\
\text { We are manipulated } \\
\text { depending on how it } \\
\text { serves politicians. }\end{array}$ & $\begin{array}{l}\text { Such images are } \\
\text { also gladly exploited } \\
\text { to arouse pity and } \\
\text { dismay. }\end{array}$ \\
\hline
\end{tabular}

Source: Author.

This is clearly distinguished when observing commentaries like the next one "We provide one of the most stupid immigration systems. Anyone may join us, regardless of whether he does fit or not into our system of values". In this argumentation, it is easy to find a xenophobic signal on the word "our values", this phrase tries, as ideological though does, simplify a more complex social 
situation. Other comments are written with the purpose of finding a responsible for the situation "With their words of welcome and the very generous benefits for asylum seekers in Europe, the German government and German media share responsibility of the large flow of refugees to Europe". This comment is inspired without doubt in the summary posted by the media in the commentaries Hungary Prime Minister Viktor Orbán referred to the refugee crisis as German problem. The Federal Republic had Syrians invited to the dinner table. After the controversial border fence, he announces new measures against asylum seekers. This is how the tragedy of a young migrant and his family is suited into an excuse to praise for further and harder actions versus migrants. In the case of Die Welt, the platform allowed to post commentaries in the same place where the news is published. But concerning the death of Aylan, Die Welt established a debate not about the event, but around the moral pertinence of showing or not the photo of the body of Aylan laying on the Turkish coast, "Ein totes Kind. Soll man es zeigen?" (The death of a child. Should we show it?). Once again, as in case of the Süddeutsche Zeitung, the event evolved into a German moral dilemma, not about the casualty itself. In between the commentaries related with the debate about publishing or not the photo, there were some significant opinions about how the action of socializing that photo was an act of exploitation "Solche Bilder werden auch gerne instrumentalisiert, um Mitleid und Betroffenheit zu erwecken" (Such images are also gladly exploited to arouse pity and dismay), or in another reader's commentary, the photo is an action of manipulation by politicians, "In Muslimischen Ländern sieht man solche Bilder jeden Tag, warum wird das jetzt auf einmal weltweit gezeigt? Wir werden manipuliert je nachdem wie es Politikern dient" (In Muslim countries we see such pictures every day, why is this now shown to the world? We are manipulated depending on how it serves politicians). One more time the composition of information in the news took the debate far from the event into a more controversial and exposure discussion.

Regarding commentaries pro-migrants or that support the actions of helping migrants is remarkable that many of them tend not to suggest a possible solution to relief the situation or to express a specific action to improve refugee conditions on camps, but to manifest their discontent with international authorities, the capitalism or against global warming! "Wir bekommen eine Ahnung, welche Zuwanderung uns erwartet, wenn es der Weltgemeinschaft nicht gelingt, die drängendsten globalen Probleme zu lösen, wie z.B. Erderwärmung" (We get a clue of which kind of immigration awaits us if the international community does not succeed in solving the most urgent global problems, such as global warming), "Heil dem Kapital!! Und möge es sich vermehren. Es ist nur ein Zeichen unserer Zeit, dass Menschen nichts mehr wert sind und nur noch als Humankapital bezeichnet werden" (Hail to the capital!! And it may multiply. It is just a sign of the time in where people are worthless and referred only as 
human capital). Both comments mirror how public concern could sometimes mislead the main point and, unintentionally, affect the same interest they are trying to help. However, there are some other comments that were related directly with the causes and possible solutions of the migration crisis, as the next one, "Ich war vor Kurzem im Krankenhaus, meine Hauptkrankenschwester war Bosnierin, die meisten anderen Pflegekräfte und auch Teile der Ärzteschaft keine Deutschen. Mit allen war ich sehr zufrieden. Deutschland wird mittelund langfristig auch von diesen Flüchtlingen sehr profitieren" (I was recently in the hospital, my main nurse was Bosnian, most other nurses and also part of the medical staff were not German. With all I was very pleased. Germany, in the mid and long term, benefits from these refugees). Some others linked migration crisis with economic disaster, as in the case of many refugees that fled their homeland because scarcity originated from war and political instability, nonetheless, at the end, they appeal to a moral point to support their arguments, as in the next one "Deren Wirtschaft wird bewusst zerstört. Ja, WIR sind verantwortlich für das Elend" (Their economy is deliberately destroyed. Yes, WE are responsible for the misery).

\section{Conclusions}

As it was possible to observe in the German news and user's commentaries, the way of how information is displayed not only conditions public reactions, but it could transform real events into ambiguous and controversial points, and to let the door open to further divisive interpretations. In the case of news readers, many of them do not even consider themselves as racist, but as the analysis of commentaries states, it is possible to indirectly express the same ideological points against a particular minority. Expressions like "they do not share our values" or assuming that almost all refugees are not in real danger and just want to enjoy free welfare are used towards Syrian or African migrants. But even in the case of people that really want to aid migrants, to blame "capitalism" or "global warming" is an action that only deludes the main point and takes the discussion to a place that will produce difficult concrete plans to solve the migrants' situation.

Considering the role of media in the construction of public opinion about controversial topics, a more ethical and compromised media is required, the action of providing information is not enough. When informing around controversial subjects like migration, it is important not to fall in uncertainty and to avoid public responsibility by framing and trivializing the main topic of the events. However, to maintain and protect media integrity is not only an isolate task but a social shared pursuit by all. In the chasing of this mission, European authorities must protect the human rights of Syrian and African refugees, and to clearly separate refugees from terrorists, and free speech from 
xenophobic and hate discourse ${ }^{25}$, applying the law as every case deserved. Consequently, in the case of terrorists, they must be prosecuted and indicted; regarding refugees they must be helped to recover and to settle properly as long as they could be able to return to their homelands. But above all, to state strict controls with "innocuous" words shared on social media, that under certain contexts, are used to normalize a xenophobic discourse, affecting vulnerable groups like migrants.

After September 2001, there has been an increasing attention toward Muslims ${ }^{26}$. This interest has been renewed with recent migration and terrorism problems, and particularly with the arrival of Donald Trump to the White House. In this context, the importance of traditional and news media, besides social and political confrontation and the uprising of the "fake news" phenomena, is undeniable. The role of media becomes vital especially when facing migration issues like the case of "dreamers" in The United States or the Syrian refugees in Europe. Yet, the function of media is not only to provide information about these cases but to question official and partial versions of the incidents. But what is most important is to avoid at all cost, not to fall into the temptation of providing simplistic explanations to multifaceted problematics.

\section{Bibliography}

ABC. Berlin Police Crack Down on Far-Right Hate Postings. ABC News, 06.04.2016. ADAM, Heribert. Xenophobia, Asylum Seekers, and Immigration Policies in Germany. Nationalism and Ethnic Politics, v. XXI, n. 4, Octubre/2015, p. 446-64. AMELINA, Anna; HORVATH, Kenneth; MEEUS, Bruno. Migration and Social Transformation: Interdisciplinary Insights and European Perspectives. In AMELINA, Anna; Kenneth HORVATH; Bruno MEEUS (coords.). An Anthology of Migration and Social Transformation. New York: Springer International Publishing, 2016, p. 1-13.

BAKER, Paul; GABRIELATOS, Costas; MCENERY, Tony. Discourse Analysis and Media Attitudes: The Representation of Islam in the British Press. New York: Cambridge University Press, 2013.

BBC. The Press in Germany. BBC News, 31.10.2006.

BENWELL, Bethan; STOKOE, Elizabeth. Discourse and Identity. Edinburgh: Edinburgh University Press, 2006.

CLARE, Matthew; ABDELHADY, Dalia. No longer a waltz between red wine and mint tea: The portrayal of the children of immigrants in French newspapers (20032013). International Journal of Intercultural Relations, v. 50, Enero/2016, p. 13-28.

\footnotetext{
${ }^{25}$ ABC. Berlin Police Crack Down on Far-Right Hate Postings.

${ }^{26}$ BAKER, Paul, GABRIELATOS, Costas, MCENERY, Tony. Discourse Analysis and Media Attitudes: The Representation of Islam in the British Press.
} 
COHEN, Roger. Germany, Refugee Nation. The New York Times, 22.12.2015.

DEL BARRIO, Ana. No es lo mismo ser refugiado en Alemania que en España. El Mundo, 08.09.2015.

FADAEE, Simin. The Immigrant Rights Struggle, and the Paradoxes of Radical Activism in Europe. Social Movement Studies, v. 14, n. 6, 2015, p. 733-739.

GEWORKIAN, Alexej. 'Crisis migratoria' en Alemania, acciones racistas y solidaridad con los refugiados. La Izquierda Diario, 29.08.2015.

GIGONA, Radina; HUME, Tim. Mob calls for assaults on migrants in Sweden. CNN International, 31.01.2016.

HESS, Sabine; TSIANOS, Vassilis. Europeanizing Transnationalism! Provincializing Europe! - Konturen eines neuen Grenzregimes. In Transit Migration Forschungsgruppe (coord.). Turbulente Ränder: Neue Perspektiven auf Migration an den Grenzen Europas. Berlin: Verlag, 2015, p. 23-39.

HOLMES, Seth M.; CASTAÑEDA, Heide. Representing the 'European Refugee Crisis' in Germany and beyond: Deservingness and Difference, Life and Death. American Ethnologist, v. 43, n. 1, February/2016, p. 12-24.

JANKS, Hilary. Critical Discourse Analysis as a Research Tool. Discourse: Studies in the Cultural Politics of Education, v. 18, n. 3, December/1997, p. 329-42.

JONES, Rodney H. Discourse and Digital Practices: Doing Discourse Analysis in the Digital Age. London, New York: Routledge, 2015.

KIRKWOOD, Steve; SIMON Goodman; MCVITTIE, Chris; MCKINLAY, Andy. The Language of Asylum. UK: Palgrave Macmillan, 2016.

O'KEEFFE, Anne. Media and Discourse Analysis. In GEE, James; HANDFORD, Michael (eds.). The Routledge Handbook of Discourse Analysis. London: Routledge, 2012, p. 441-454.

OLSEN, Christopher; EL-BIALY, Rowan; MCKELVIE, Mark; RAUMAN, Peggy; BRUNGER, Fern. 'Other' Troubles: Deconstructing Perceptions and Changing Responses to Refugees in Canada. Journal of Immigrant and Minority Health, v. 18, n. 1, February/2014.

RAMBE, Patient. Critical Discourse Analysis of Collaborative Engagement. Australasian Journal of Educational Technology, v. 28, n. 2, 2012, p. 295-314.

RETTBERG, Jill Walker; RADHIKA, Gajjala. Terrorists or cowards: negative portrayals of male Syrian refugees in social media. Feminist Media Studies, v. 16, n. 1, January/2016, p. 178-181.

SLAVÍČKOVÁ, Tess; ZVAGULIS, Peter. Monitoring anti-minority rhetoric in the Czech print media: A critical discourse analysis. Journal of Language and Politics, v. 13, n. 1, January/2014, p. 152-170.

SMALE, Alison. Germany's Embrace of Migrants Spawns Rise of Far-Right Leader. The New York Times, March/2016.

TEO, Peter. Racism in the News: A Critical Discourse Analysis of News Reporting in Two Australian Newspapers. Discourse \& Society, v. 11, n. 1, January/2000, p. 7-49. 
VAN DIJK, Teun A. Critical Discourse Analysis. In SCHIFFRIN, Deborah; TANNEN, Deborah; HAMILTON, Heidi E. (coords.). The Handbook of Discourse Analysis. Oxford: Wiley-Blackwell, 2003.

Received for publication in July $21^{\text {st }}, 2017$ Accepted for publication in September $12^{\text {th }}, 2017$ Recebido para publicação em 21.07.2017 Aceito para publicação em 12.09.2017

ISSN impresso 1980-8585

ISSN eletrônico 2237-9843

http://dx.doi.org/10.1590/1980-85852503880005107 